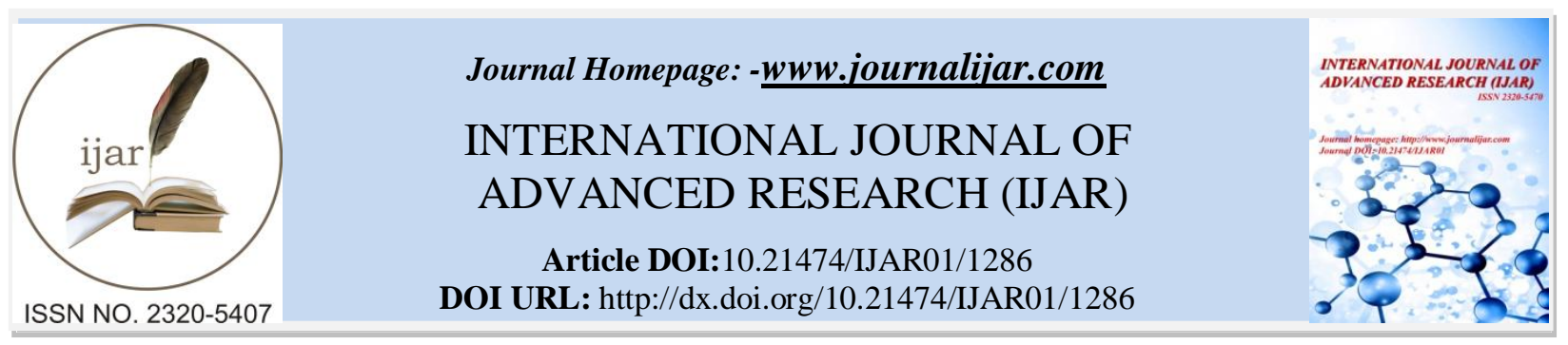

RESEARCH ARTICLE

\title{
HISTORY OF IBAN POPULAR MUSIC, AN ALTERNATIVE CONCEPTIONS OF MODERNITY
}

\section{Lim, C. K. $\mathrm{N}^{1}$, Durin, $\mathrm{A}^{2}$, Chelum, $\mathrm{A}^{3}$ and Mohamad Maulana Magiman ${ }^{4}$.}

1. Department of Performing Arts and Production Technology, Faculty of Applied and Creative Arts, Universiti Malaysia Sarawak, 94300 Kota Samarahan, Sarawak, Malaysia.

2. Department of Liberal Art, Faculty of Applied and Creative Arts, Malaysia Sarawak, 94300 Kota Samarahan, Sarawak, Malaysia.

3. Department of Liberal Art, Faculty of Applied and Creative Arts, Universiti Malaysia Sarawak, 94300 Kota Samarahan, Sarawak, Malaysia.

4. Department of Social Sciences, Faculty of Agriculture and Food Sciences, Universiti Putra Malaysia, Sarawak Campus, 97008 Bintulu, Sarawak, Malaysia.

\section{Manuscript Info}

Manuscript History

Received: 12 June 2016

Final Accepted: 22 July 2016

Published: August 2016

Key words:-

Iban, Modernity, Popular Music,

Christianity, Education, Colonization, Nationalism.

\section{Abstract}

The Iban make up one third of the Sarawakian population and are the largest indigenous ethnic group in Sarawak, Malaysia. As with other ethnicities in the nationstate, modernity has presented challenges for socio-cultural development and lifestyle of Iban people. The objective of this paper is to examine how modernity has historically shaped developments in the industry of Iban popular music. Historically, the Iban are a cultural group located geographically and politically on the periphery of the multi-cultural nation of Malaysia. Throughout much of the 20th century, the music industry has experienced a rapid embrace of modernity through the nation to the detriment of traditional practices in culture in order to adapt them in the era of modernization. Hence, the Iban society had gone through a state of flux where people have gone through the process of readapting themselves in meeting the demanding challenges of Malaysian nationalism. Drawing upon alternative conceptions of modernity to evaluate how the Iban reference both a national as well as a local music industry particularly through their use of language as an expression of Iban. Changes in Iban society through political and economic modernization had led to the emergence of Iban popular music industry because of relative exposure to agents of change such as the influence through Christian missionary and education. This reflects how the Iban react and reflect in adaptation of modern demands of change as a result of the effects of historical processes on the social, cultural and physical environments. 


\section{Introduction:-}

Modern, modernity, modernization, modernism are the terms used spontaneously in describing a transformation of socio-historical process these days. Objectively, modernity is seen as a "process of modernization, by which the social world comes under the domination of asceticism, secularization, the universalistic claims of rationality and differentiation of various spheres of the lifeworld, bureaucratization of economic, political and military practices, and the growing monetarization of values" (Turner, 1990:6). As the basis of modernity consist of historical, cultural and social formations (Mee \& Kahn, 2012) and includes large areas of social process and cultural orientation comprised of globalization, transnationalism, nationalism, identity, the state, secularism capitalism, technorationality and religion.

From the colonial period to postcolonial era, Southeast Asia nation states have gone through dramatic historical developments and experienced political and economic changes. But looking at the history of popular music through the lense of the nation does not in itself produce the whole picture. Instead Barendregt (2014) proposes 'alternative conceptions of modernity' that problematize nation-centered narratives about the history of popular musics in Southeast Asia. Barendregt observes that modernity's production of new fashions, markets and lifestyles offers, "... a glimpse of how and why people have taken up ideas of the modern, how it is made, unmade and remade, paying ample attention to how such reconfigurations may serve various claims and are constantly haunted by yet others" (Barendregt, 2014:6). The objective of this paper is to investigate how modernity has historically shaped developments in the industry of Iban popular music. These refers to the key players in popular music industry, how and why popular music is produced and created is to meet the market demand and the current needs of musical taste at that particular era. As a desire to be modern, it is a need to attempt and to fit into the current needs at that particular space and time period, as well as create their own trends and developments within the society.

\section{Theoretical Framework:-}

Recognizing the defiance of Western modernity, 'alternative conceptions of modernity' avoids nation-centered narratives and takes a holistic approach towards examining the multiple ways in which popular music are attached to socio-culture developments in society. Some of the multiplicity of factors include issues of socio-economic and stages of socio-cultural development, educational development, Christianity, literacy, as well as stages of economic development in infrastructure, lifestyle and technology. All have been critical factors influencing definitions of modernity in the Iban society. The Iban in Sarawak have encountered various waves of modernization since the arrival of James Brooke in August 1839 where the history of Sarawak as a modern nation-state began (Kedit, 1980). Adapting to the new environment after the arrival of Western influence, the Brookes controlled, administered and maintained order to prepare the Iban to meet the needs and demands of a modern economy.

During the Brooke administration, influence from the Christian missionary and education had exposed the Iban to Western Music through hymn singing where they were exposed to Western melodic structures and harmony through the expectation of memorizing the hymns. Since 1950s, the Saribas Iban had listened to the radio on regular basis (Postill, 2006), the Iban established their contact to Western, Malay and Indonesian popular music played by the radio station. With radio providing a model, the Iban soon accelerated these innovations creating their own popular music, while expressing Ibaness through their own language, they adapted Western pop music melodies into their own early creations of pop music. Nevertheless, mimicking could also be seen as a reconfiguration in conveying their culture and expressions as social entertainment.

Looking as form of mass communication, popular music could serve as a mediator to communicate the 'desirability of modernity' as one of the ways to achieve rational development in the society (Hobart, 2006). As the modern infrastructure development is happening in the longhouse environment, the young girls are eager to follow the western entertainment, pop music, dancing the way the western people dress in the longhouse in order to be modern (Kedit, 1980). Consequently, as the desire of Iban to be modern, it had created a space in pop music creation and learning the music making process in innovating the Western, Malay and Indonesian music style into the newly created pop music. Hence, pop music had opened up the opportunity for the Iban to perform on stage and participating in singing competition had created the space among the community to explore their talent and skills in music. 


\section{The Emergence of Iban Radio Broadcasting and Iban Popular Music:-}

Popular music influences from Kuala Lumpur, Penang as well as Indonesia have been considerable throughout the history the Iban popular music. These popular music styles have dictated from the centre to the 'periphery' where the Iban music industry is located in Sarawak. This "center-periphery" paradigm certainly describes the emergence of Iban popular music industry in Sarawak from 1954-1976, an era that gave rise to Iban radio broadcasting.

Radio Sarawak was officially established on the $8^{\text {th }}$ of June 1954, when the Sarawak Legislative Council decided to create a broadcasting service with technical assistance from the British Broadcasting Corporation (BBC). Among the four broadcast programs, including Malay, Iban, Chinese and English, the Iban programming was initially broadcast for just one hour from 7-8pm daily. In the early days, the programs were limited to news, information on agriculture and animal husbandry, Iban folklore, but also included sung poems (pantun, renong) and epics (ensera). In the 1950s, external musical influences from the Indonesian and Indian pop music dominated Iban airwaves and in the 1960s and 1970s, British and American popular music received substantial airplay. Radio Sarawak listeners enjoyed songs sung in Malay, Indonesian as well as English sung by British and American artist. Therefore, in order for an emerging Iban pop music industry to modernize, they composed songs using a popular form of their own language.

Both sisters, Senorita Linang and Pauline Linang were brought up listening to Western songs on the Sarawak Radio. Among their favourites were Tom Jones and Engelbert Humperdinck (Postill, 2006). Senorita Linang was an Iban beauty pageant winner and she was very much seen in the public eye as an icon of Ibanness. As an Iban singer cum artist, she was often perceived as a central icon to urban Iban audiences. She became the voice of Iban popular music in places where her songs reached her listeners in Sarawak through medium or shortwave frequency radio transmission. But she may also be considered as a periphery artist among the larger, more dominant Kuala Lumpur, Indonesian and Western artists promoted at the time. As a majority ethnicity of Sarawk, the Iban established themselves through the vehicle of popular music yet predictably remained a minority in larger urban centres.

In the 1970s, Christopher Kelly emerged in the Iban pop music industry after winning the RTM star competition (Pertandingan Bintang RTM).His first album entitled 'Beraie Nganti' was recorded in the 1970s and it received an overwhelming response from Iban music fans. He was crowned as the most popular Iban artist in 1970s and the first Iban artist who had performed together with the RTM orchestra for National Day in year 1973. 'Bungai Layu', 'Nuan Meruan di Atiku', 'Agi Idup Agi Ngelaban', 'Tinggal Sari Asai Setaun', Beraie Nganti' are among the titles of Iban song which were popularized by him. In total, he had recorded 24 vinyl albums with RTM from 1970s to 1980s and each vinyl disc contain 4 songs. Positioned on the periphery, the Iban artists did borrow tunes and rhythms from Western pop songs and adapted them as their own. But influences also included Malay and Hindustani genres that may be seen in Iban popular music. As Iban songs were broadcast on the radio station, the Iban popular music might have reached a wider audience from Indonesia, especially in Kalimantan region, Malaya through radio transmission.

But Iban radio programming has not always broadcast the sounds of modernity for its Iban listerners. In 1960s, the Sarawak government used Iban radio broadcasting for psychological warfare tactics against communist insurgents. During the end of the Indonesian confrontation in 1965, priorities of broadcast shifted from warfare propaganda to 'mental revolution of the people' with the aim to educate people with health and economic development information (Postill, 2006:49). Christopher Kelly was especially brought to sing in the communist area of Sibu in the early 1970s, where the former whole Third Division of Sarawak (presently covering Sibu, Kapit, Sarikei and Mukah Divisions) was declared a special security area under the administration of Rajang Area Security Command (RASCOM) administered by the Chief Executive Officer whereas its Director of Operations is the Chief Minister of Sarawak. The places where Christopher Kelly was brought to perform as a singer cum entertainer included Pentas Rakyat (community stage show) in Nanga Ngungun operational area (Kanowit), Nanga Tada Operational area (Kanowit), Nanga Jagau operational area (Kanowit) and Nanga Sekuau operational area (Sibu) where he became the center figures of popular music.

During the communist movement of the 1960s, Iban soldiers were sent to Malaya. The song entitled 'Nganti Ti Pulai' was sung by Senorita Linang which means waiting for you to come back (Table 1). The melody of this song is taken from 'Sealed with a Kiss' in slow rock ballad sung by Brian Hyland, an American pop recording artist. The recording was released as a single in 1962. The Iban lyrics of the song portray the longing of a lover or fiancé towards a soldier. With separation as a theme, he had left her for a place far away, either for war or berjalai (literally 
means walking, acquiring new knowledge or wealth to be brought back to their village at the end of the journey). As depicted in the lyrics she misses him so much and prays he will be back soon.

Table 1:- 'Nganti Ti Pulai' (Wait for you to come back) lyrics in Iban and the translation in English.

\begin{tabular}{|c|c|}
\hline Anang nuan lama pegi & Don't go too long \\
\hline Aku ditinggal & I am left behind \\
\hline Anang ngasuh aku braie & Don't make me love sick \\
\hline Pulai lengkas sulu & Please come back as possible, my love \\
\hline Ngagai aku ti nganti & To me that waiting for you \\
\hline Anang lama pegi & Don't go too long \\
\hline Sekumbang nuan dah ngejang & Since you have been away \\
\hline Lesa idup ku & I feel so gloomy \\
\hline Puas ngasuh ati lantang & It's hard to make myself happy \\
\hline Engka ti ka badu & Hopping my gloominess will be stop \\
\hline Tang enda ulih oh sulu & But it cannot be stopped, \\
\hline Pulai lengkas kitu & Come back here soon \\
\hline Besari aku besampi & Every day I pray \\
\hline Ke nuan tetap lengkas pulai & Hope you will come back soon \\
\hline Ngelama aku udah nganti & All this long I have been waiting \\
\hline Ka nuan ti ambai lalai & For you, my love \\
\hline Anang nuan lama pegi & Don't go too long \\
\hline Lengkas pulai & Come back soon \\
\hline Aku nganti besari-sari & I wait everyday \\
\hline Ka nuan ti ka pulai & For you to come back \\
\hline Ngagai aku ti nganti tu & To me that wait for you here \\
\hline Ngambi lengkas pulai & So that you come back soon \\
\hline Besari aku besampi & Every day I pray \\
\hline Ka nuan ti tau lengkas pulai & Hope you will come back soon \\
\hline Ngelama aku udah nganti & All this long I have been waiting \\
\hline Ka nuan ti ambai lalai & For you, my love \\
\hline Ka nuan ti ka pulai & For you to come back \\
\hline Ngagai aku ti nganti tu & To me that wait for you here \\
\hline Ngambi lengkas pulai & So that you come back soon \\
\hline
\end{tabular}

As seen in the lyrics (Table 2), the song evokes an Iban battle cry 'Agi Idup Agi Ngelaban' which means literally to fight to the death. It was composed during the 1960s and sung by Christopher Kelly during the government's era of urgent 'Malaysianisation'. It depicts the current scene of Sarawak joining Malaysia especially during the communist insurgency. Kelly's voice in the song urges the Iban soldiers to sacrifice all for their country. Because the song lyrics are in Iban, not Malaysian language, it creates a strong sense spirit of comradeship, a bond between Iban soldiers who fought bravely for their rapidly modernizing nation. The style of this song is very similar to 1960s pop melayu with Malay asli ornamentation in the melody.

Table 2:- 'Agi Idup Agi Ngelaban' (Fight until death) lyrics in Iban and the translation in English.

\begin{tabular}{|l|l|}
\hline Diatu kitai udah Merdeka & Now we are a free country here \\
Pegai perintah serakup Malaysia & Governed by formation of Malaysia \\
Anang sekali bebagi ati & Don't be half hearted \\
Ngetan ke menua sereta enggau negeri & Protect your country \\
Chorus: & \\
Aram meh kitai ti nyadi sedadu & Come, those of us who are soldiers \\
\hline
\end{tabular}




\begin{tabular}{|l|l|}
\hline Berambun ka nyawa napi peluru & Sacrifice your life against the bullet \\
Anang undur ngapa ari menalan & Don't ever retreat from the war field \\
Enti agi idup agi ngelaban & Fight until your last breath \\
Kitai meh bejuluk bujang berani & We are the brave warriors \\
Ti tampak rita serta pegari & Who are famous and well known \\
\hline
\end{tabular}

Christian missionaries, formal education, as well as political and economic development dramatically changed the cultural and physical environment of the Iban as well as the Iban's perception towards their traditional culture. In addition, many Iban themselves were involved in internally discrediting their own culture. For example, traditional Iban belief systems were animistic and often involved shamans and ritual healers. As a reflection of modernization through migration to the urban, the song 'Cherita Manang Ula' (Story of 'Manang Ula') (Table 3) portrays the urban Iban's skeptical attitude towards the rural Iban traditional animism healing rituals. These were conducted by Iban shaman known as manang. Sung in the rhythm and melody is taken from Indonesian song with an exotic Hindustani flavor, this song depicts how a bogus shaman conducted a phony healing ritual.

Table 3:- 'Cherita Manang Ula' (Story of 'Manang Ula') lyrics in Iban and the translation in English.

\begin{tabular}{|c|c|}
\hline Dinga kita cherita & Listen to the story \\
\hline Aki manang ula & Shaman 'manang ula' \\
\hline Lebuh iya di ambi & When he was invited \\
\hline Orang belian & For healing ritual \\
\hline Puchung sakarung & Bundle of charms \\
\hline Di ma enggau baka & In a basket he carried on his back \\
\hline Endang siku orang & One men \\
\hline Di asoh iya ngesan & Ask him to carry \\
\hline Leboh iya datai & When he arrive \\
\hline Ba tudah ke sakit & At the place of the sick \\
\hline Dia iya nanya & Then he ask \\
\hline Nama pemedis & What kind of sickness \\
\hline Tudah ke sakit & The poor sick person \\
\hline Pan madah diri & He tell about himself \\
\hline Kena hujan nyala & Because of the 'hujan nyala' \\
\hline Pulai iya nginti & When he comes back from fishing \\
\hline Manang ula lalu & Shaman 'manang ula', then, \\
\hline Enda chamang-chamang & Immediately \\
\hline Mantai ka lupong & Take his basket \\
\hline Batu pemandang & Batu pemantang (Crystal to see kind of sickness) \\
\hline Dia iya lalu & Then he start \\
\hline Muchau besampi & Recite the speal \\
\hline Mandang ke batu & Looking at the crystal \\
\hline Segenap tisi & In every angle \\
\hline Batu iya kumbai & That crystal he called \\
\hline Iya batu ilau & As 'batu ilau' (crystal for seeing) \\
\hline Di kena nenggau & For him to see \\
\hline Ngabas penyakit & Find out the sickness \\
\hline Udah nya baru & After that, \\
\hline Iya mantai puchau & He start recite the spell \\
\hline Di kena ngabau antu ti jai & For him to ward away the bad spirits \\
\hline
\end{tabular}




\section{Shaping Modernity in the History of Iban Popular Music: The Way Forward:-}

After fifty one years as being part of Malaysia nation state, the Iban popular music industry certainly has grown by leaps and bounds. The Iban had encountered the wave of modernization and modernity ever since the arrival of James Brooke in August 1839 when the history of Sarawak as modern nation-state began (Kedit, 1980). Since 1950s, the Iban had started to listen to radio on regular basis. Through radio broadcast, the Ibans are exposed to Western, Malay and Indonsian popular music. Negotiating modernity, the Ibans are following the steps and the development trend of popular music through the source of radio. They soon accelerated these innovations creating their own popular music, while expressing through Iban language, they adapted the Western and Malay popolar music melodies in 1950s to 1960s in their early creation of pop music. Although mimicking could be seen in early Iban pop music, it is an agent of change in conveying their culture and expression of life in social entertainment.

In 1970s, the Iban music industry started to grow as a entertainment business Kuching, Sibu, Bintulu and Miri. Lim \& Durin (2013) had traced the Iban popular music in 1970s are influenced from Western, Hindustani and pop Melayu style. Concurrently, Salok (2014) provides a brief overview on the development of Iban music industry. This had indirectly contributed to the economic growth and diversification in particular, generally in Sarawak, as well as urbanizing the Iban population with the increasing demand of modern forms of entertainment which is not available through the television. Today, Iban popular music could be consider as regional pop music in Sarawak has continue to develop. Modernity is nowhere to be seen in the recording cover of the vinyl disc, cassette tapes, CD and VCD cover illustrated the dynamic urban persona devoid of any ethnic markers: the singers wear Western-style clothing and modern accessories such as sunglasses.

Through the past 51 years, the Iban music industry has certainly grown by leaps and bounds in producing news artist as well as new recording albums over the past 51 years. But, the question raised by Salok (2014) in searching the real identity of Iban popular music at the same time looking for the right direction to further develop the industry. Simultaneously, Bidin (2014) had succeeded to identify the issues focused on the power of thoughts in the Iban song lyrics as well as identify the Iban responsibility and culture from the song lyrics. The subject of Iban popular song lyrics are dealing with vagaries of human heart (Postill, 2006), ranging from broken heart, longing heart, happy heart, ode to Sarawak and the meaning of life. According to Postill (2006), apart from painful subject of love, they also touches on current social problem, migration, distinction and barriers of social classes and inequalities brought by education. Through the findings and observation by Postill (2006), Lim \& Durin (2013), Salok (2014) and Bidin (2014), I am strongly convinced and believed the Iban pop music is successfully being commercialized, disseminated throughout the state of Sarawak as a commodity and a product distributed through the mass media such as radio network, recordings in DVD, VCD and CD formats, social media network such as Facebook and YouTube, newspaper and magazines and live performances in pub, restaurant, open-air venues and longhouse during public functions, festivals and events.

\section{Conclusion:-}

This paper has addressed how 'alternative conceptions of modernity' have shaped and contributed to the musical development and socio-culture meaning of Iban pop music in Sarawak. Popular music in Iban society has endured influence from the hymns and Christian liturgy rendered into Iban language, English songs sung in mission schools, a mixture of Western, Malay and Indonesian pop songs and the diffusion of Western and Malay music into the Iban community. Since the beginning of radio station broadcasts, Iban popular music has been a strategic form of media towards nation building especially in the era of Malaysianisation when Sarawak joined Malaysia as a nation state. Due to the limited sources of music available to the Sarawak listeners at that time, the uniqueness of Iban pop is seen through the mixture of various genres of popular music ranging from Malay pop, Indonesian dangdut, Hindustani music, and Western ballads. It shows how these musical concepts blend together with the Iban language in the form of purely entertainment-based popular music. Although Iban pop music is not fully original composition, the pop music reflects the popular culture and lifestyle of Iban people especially how Iban people express their culture as well as their identity of Ibanness in the modernized environment. 


\section{Bibliography:-}

1. Barendregt, B. (2014). Sonic Histories in a Southeast Asian Context. In Sonic Modernities in the Malay World: A History of Popular Music, Social distinction and Novel Lifestyles (1930s-2000s) (pp. 1-43). Leiden: Brill.

2. Bidin, E. B. (2014). Tanggung Pengawa enggau Daya Idup dalam Lagu Iban. Ngingit, 6, 140-152.

3. Hobart, M. (2006). Introduction: why is entertainment television in Indonesia important? Asia Journal of Communication, 16(4), 343-351. http://doi.org/10.1080/01292980601012352

4. Kedit, P. M. (1980). Modernization among the Iban of Sarawak. Kuala Lumpur: Dewan Bahasa Dan Pustaka.

5. Lim, C. K. N., \& Durin, A. (2013). Iban Popular Music in 1970s. In KABOKA 7 (Konferensi Anta-Universiti Se Borneo Kalimantan Ke-7. Kota Samarahan: Universiti Malaysia Sarawak.

6. Mee, W., \& Kahn, J. S. (2012). Introduction. In Questioning Modernity in Indonesia and Malaysia. Singapore: National University of Singapore and Kyoto University Press.

7. Mee, W., \& Kahn, J. S. (2012). Introduction. In W. Mee \& J. S. Kahn (Eds.), Questioning Modernity in Indonesia and Malaysia (pp. 1-17). Singapore: NUS Press in association with Kyoto University Press.

8. Parladir, H. S. (2014). Diaspora Studies in Social Sciences: Modernity, Power and Identity. Journal of Süleyman Demirel University Institute of Social Sciences, (20), 101-125.

9. Postill, J. (2006). Media and Nation Building: How the Iban became Malaysia. New York, Oxford: Berghahn Books.

10. Salok, V. T. (2014). Industri Musik Iban: Majak Mansang Taja Agi Bisi Penimpang. Ngingit, 135-139.

11. Tan, S. B. (2012). Introduction: Representations in The Creative Arts of Southeast Asia, Negotiating Meanings and Identities. Wacana Seni Journal of Arts Discourse, 11, 1-17.

12. Turner, B. S. (1990). Periodization and Politics in the Postmodern. In Theories of Modernity and Postmodernity (pp. 1-13). London: Sage Publications Ltd.

13. Wallach, J., \& Clinton, E. (2013). History, Modernity, and Music Genre in Indonesia: Popular Music Genres in the Dutch East Indies and Following Independence. Asian Music, 44(2), 3-23. http://doi.org/10.1353/amu.2013.0020 